\title{
HORMONAL INFLUENCES ON TUMOUR GROWTH IN THE UTERUS OF THE RAT
}

\author{
R. V. SHORT AND K. YOSHINAGA \\ Department of Veterinary Clinical Studies and \\ A.R.C. Unit of Reproductive Physiology and Biochemistry, University of Cambridge
}

(Received 31st Fanuary 1967)

\begin{abstract}
Summary. The Walker carcinosarcoma was inoculated into the uterine lumen of the following six groups of rats: (1) Normal oestrous cycles, (2) ovariectomized, (3) ovariectomized $+2 \mathrm{mg}$ progesterone daily, (4) ovariectomized $+2 \mathrm{mg}$ progesterone $+2 \mu \mathrm{g}$ oestradiol-17 $\beta$ daily, (5) ovariectomized $+2 \mathrm{mg}$ progesterone daily + a single injection of $0.2 \mu \mathrm{g}$ oestradiol-17 $\beta$ on the day of tumour transplantation, and (6) pseudopregnant, Day 5.

Whilst the tumour grew well outside the uterus in all groups, tumour tissue only invaded the uterine wall in Groups 5 and 6. Growth was most marked in the pseudopregnant animals, where the tumour was actively invading the anti-mesometrial decidua. In Groups 3 and 5, the uterine lumen was full of extravasated blood and polymorphonuclear leucocytes, whereas in Groups 1, 2 and 4 the uterus appeared normal, with no signs of any tissue reaction.

It is concluded that the tumour behaves very like the blastocyst; its ability to survive within the uterus is hormone dependent, whereas it can develop outside the uterus irrespective of the hormonal environment. The mechanisms by which a hostile endometrium can destroy the tumour are not known.
\end{abstract}

\section{INTRODUCTION}

Recent studies on delayed implantation in some Australian marsupials (Tyndale-Biscoe, 1963) and in the roe deer (Capreolus capreolus) (Short \& Hay, 1966) suggest that the condition is in fact a true embryonic diapause; it would seem that the uterus can in some way suppress the normal mitotic activity of the developing blastocyst.

Delayed implantation can be induced experimentally in the rat (Ganivenc \& Laffargue, 1956; Cochrane \& Meyer, 1957) and there is some evidence that in this species, too, the delay is brought about by an arrest in the mitosis rate of the developing blastocyst (Baevsky, 1963).

It therefore seemed worthwhile to study the influence of the uterus on the growth rate of other types of cells. We have investigated the fate of a malignant tumour transplanted to the uterine lumen of rats under a variety of different hormonal conditions. 


\section{MATERIAL AND METHODS}

Forty 3- to 4-month-old rats of the Chester Beatty strain of Wistar rat, obtained from the Chester Beatty Research Institute, were used in these experiments. The oestrous cycles were followed daily by means of vaginal smears. Pseudopregnancy was induced in some animals by cervical stimulation on the day of oestrus. Ovariectomies were carried out by the dorso-lateral route.

The tumour used was the Walker carcinosarcoma 256, maintained by serial passage in rats of the same strain at the Chester Beatty Research Institute; after subcutaneous implantation, this tumour will normally kill a rat in 14 days (Rosenoer, Mitchley, Roe \& Connors, 1966). The tumour was harvested from a subcutaneous site 7 days after inoculation, and prepared with a tissue sieve as a cell suspension in saline. This was transported to Cambridge in a thermos flask on ice, and used within $6 \mathrm{hr}$ of harvesting.

After anaesthetizing the rats with ether, $0.01 \mathrm{ml}$ of the tumour suspension was injected into the lumen of each uterine horn with the aid of a micrometer syringe. In order to exclude the possibility that the tumour might be expelled from the uterus, ligatures were placed above and below the site of injection in one of the uterine horns. However, in none of the animals was there any obvious difference in the behaviour of the tumour as between ligated and unligated horns.

An aliquot of the tumour suspension was placed in a hremocytometer, and the cells counted. The total number of cells injected into each uterine horn of all the animals was 190,000 to 270,000 .

The recipient rats were divided into the following six experimental groups:

Group 1. Normal oestrous cycles (six rats)

Two of the animals were in oestrus, three in di-oestrus and one in pro-oestrus at the time of inoculation.

\section{Group 2. Ovariectomized (five rats)}

The operation was performed 4 days before inoculation of the tumour.

\section{Group 3. Ovariectomized + progesterone (five rats)}

Two milligrams of progesterone in oil were injected subcutaneously every day for 11 days, beginning on the day of ovariectomy. The tumour was inoculated on the 4th day of treatment.

\section{EXPLANATION OF PLATE 1}

Fig. 1. T.S. uterus from an ovariectomized rat treated with progesterone alone (Group 3). The section is taken through the deciduoma formed at the site of ligation of the uterus. Decidual tissue is visible antimesometrially, and the uterine lumen is distended with blood. The tumour has failed to grow. $x 11$.

Fig. 2. T.S. uterus from an ovariectomized rat treated with progesterone and given a single injection of $0.2 \mu \mathrm{g}$ oestradiol-17 $\beta$ (Group 5). Tumour tissue has invaded the antimesometrial decidua, and is confluent with an extensive tumour mass outside the uterus. $\times 6$.

Fig. 3. T.S. uterus from a pseudopregnant rat (Group 6). Massive invasion of the antimesometrial decidua by tumour tissue. $\times 6$.

Frg. 4. Section through the decidual tissue of a pseudopregnant rat (Group 6). Darklystaining tumour cells are invading the deciduoma, and a number can be seen in mitosis. $\times 420$. 
PLATE 1

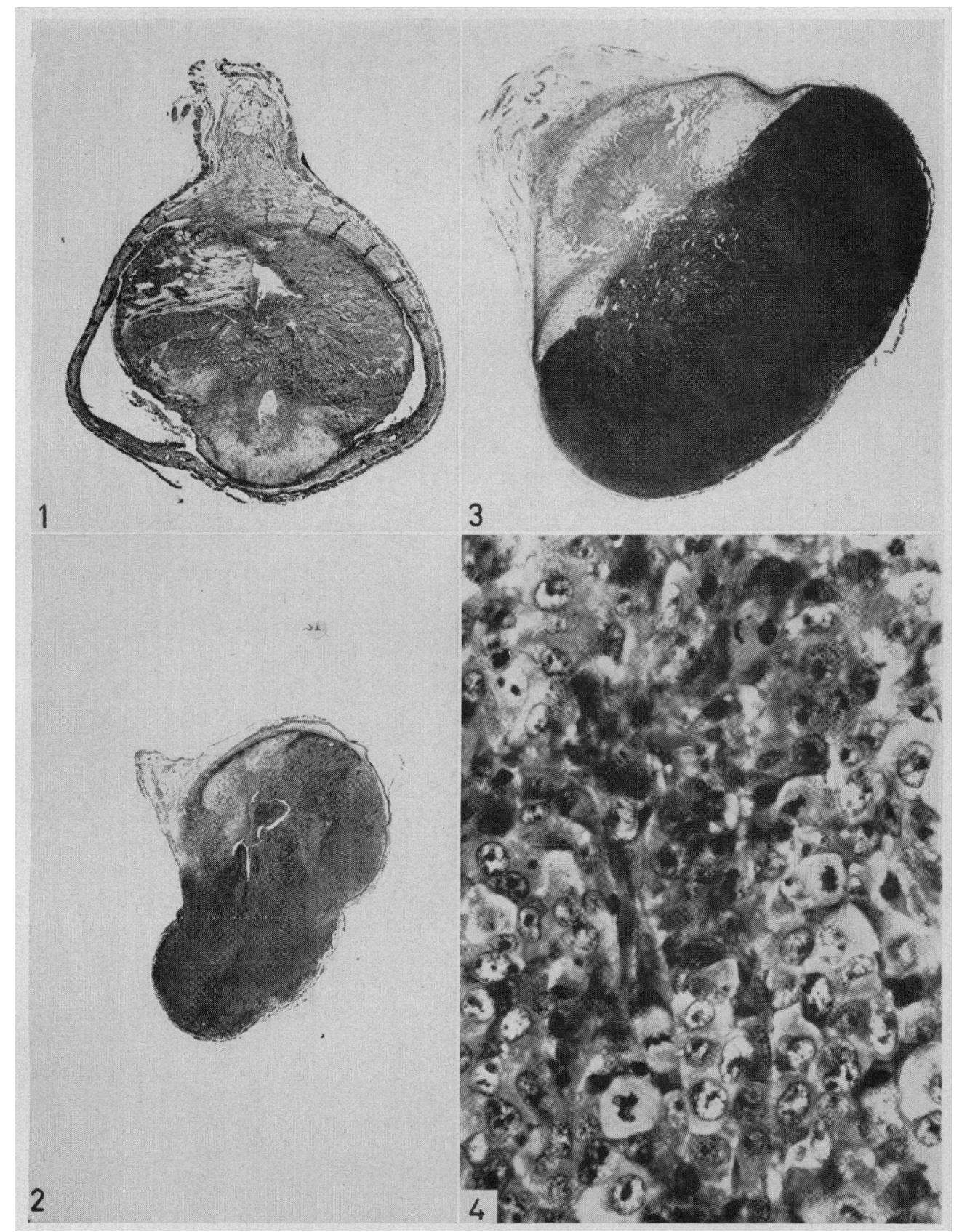

(Facing p. 288) 
Group 4. Ovariectomized + progesterone +oestrogen (seven rats)

Two milligrams of progesterone and $2 \mu \mathrm{g}$ of oestradiol-17 $\beta$ were injected, as in Group 3.

Group 5. Ovariectomized +progesterone + a single injection of oestrogen (ten rats)

Two milligrams of progesterone were injected as in Group 3; on the 4th day of treatment, when the tumour was inoculated, a single injection of $0.2 \mu \mathrm{g}$ oestradiol-17 $\beta$ was also given.

Group 6. Pseudopregnant (seven rats)

The tumour was inoculated on the 5th day of pseudopregnancy (day of oestrus $=$ Day 1 of pseudopregnancy).

All the animals were killed 7 days after inoculation of the tumour and opened by a mid-ventral incision. After noting whether any tumour mass was present in the peritoneal cavity, the uterus was removed, trimmed and weighed. It was then fixed in $10 \%$ formol saline for subsequent histological examinations. These were usually confined to areas of the uterus where there were obvious swellings. Tumour tissue from a number of extra-uterine sites was also examined histologically. Sections were cut at $5 \mu$ and stained with haematoxylin and eosin.

\section{RESULTS}

All the results are presented in Table 1.

Group 1. Normal oestrous cycles

It can be seen from Table 1 that none of these animals had any tumour growth in the uterus, although in two of them the tumour had developed outside the uterus in the adipose tissue around the ovaries. Both of these animals showed a prolonged di-oestrous period, whereas the other four animals continued to have normal oestrous cycles.

\section{Group 2. Ovariectomized}

The tumour failed to develop in the uterus of any of these animals, and the uterine weights reflect the effect of ovariectomy. However, in four of the animals there was a good growth of tumour outside the uterus.

\section{Group 3. Ovariectomized + progesterone}

The uteri were noticeably enlarged and distended with blood. On histological examination, the uterine lumen was seen to be filled with red cells, polymorphonuclear leucocytes and a few large cells of unknown origin. Most of the animals showed a decidual cell reaction, especially where the uterus had been ligated, but at no point had the tumour invaded the uterine tissues. Some of these changes are seen in Pl. 1, Fig. 1. The tumour had grown well outside the uterus in all these animals.

Group 4. Ovariectomized + progesterone + oestrogen

Although the uterine weights were considerably increased in all these animals, this was largely due to the accumulation of fluid in the lumen of the 
uterus between the two ligatures, where there had been considerable distension. In contrast to the Group 3 animals where the uteri were darkened by the presence of blood in the lumen, the uteri of the animals in Group 4 were trans-

TABLE 1

GROWTH OF THE WALKER CARGINOSARCOMA TRANSPLANTED TO UTERI OF RATS IN VARIOUS ENDOGRINE STATES

\begin{tabular}{|c|c|c|c|c|c|}
\hline \multirow{2}{*}{ Experimental group } & \multirow{2}{*}{ Rat No. } & \multirow{2}{*}{$\begin{array}{c}\text { Uterine } \\
\text { weight } \\
\text { (g) }\end{array}$} & \multirow{2}{*}{$\begin{array}{l}\text { Decidual } \\
\text { response }\end{array}$} & \multicolumn{2}{|c|}{ Presence or absence of tumour } \\
\hline & & & & Outside uterus & Inside uterus \\
\hline 1. Normal cycles & $\begin{array}{l}1 \\
2 \\
3 \\
4 \\
5 \\
6\end{array}$ & $\begin{array}{l}0.634 \\
0.539 \\
0.977 \\
0.567 \\
1.235 \\
0.413\end{array}$ & $\begin{array}{l}- \\
- \\
- \\
- \\
-\end{array}$ & $\begin{array}{l}- \\
\overline{-} \\
\pm \\
+\end{array}$ & $\begin{array}{l}- \\
\overline{-} \\
\overline{-} \\
-\end{array}$ \\
\hline 2. Ovariectomized & $\begin{array}{r}7 \\
8 \\
9 \\
10 \\
11\end{array}$ & $\begin{array}{l}0.249 \\
0.238 \\
0.215 \\
0.210 \\
0.210\end{array}$ & $\begin{array}{l}- \\
\overline{-} \\
\overline{-} \\
-\end{array}$ & $\begin{array}{l}+ \\
+ \\
+ \\
+ \\
+\end{array}$ & $\begin{array}{l}- \\
\overline{-} \\
\overline{-}\end{array}$ \\
\hline $\begin{array}{l}\text { 3. Ovariectomized }+ \\
\text { progesterone }\end{array}$ & $\begin{array}{l}12 \\
13 \\
14 \\
15 \\
16\end{array}$ & $\begin{array}{l}0.774 \\
1.042 \\
0.969 \\
1.563 \\
2.358\end{array}$ & $\begin{array}{l}+ \\
+ \\
+ \\
+\end{array}$ & $\begin{array}{l}+ \\
+ \\
+ \\
+ \\
+\end{array}$ & $\begin{array}{l}\overline{-} \\
\overline{-} \\
\overline{-}\end{array}$ \\
\hline $\begin{array}{l}\text { 4. Ovariectomized }+ \\
\text { progesterone } \\
\text { + oestrogen }\end{array}$ & $\begin{array}{l}17 \\
18 \\
19 \\
20 \\
21 \\
22 \\
23\end{array}$ & $\begin{array}{l}2.002 \\
0.811 \\
1.741 \\
2 \cdot 174 \\
1.296 \\
1.187 \\
2.011\end{array}$ & $\begin{array}{l}z \\
z \\
z \\
z \\
-\end{array}$ & $\begin{array}{l}+ \\
+ \\
+ \\
+ \\
+ \\
+ \\
+\end{array}$ & $\begin{array}{l}z \\
z \\
z \\
z \\
-\end{array}$ \\
\hline $\begin{array}{l}\text { 5. Ovariectomized }+ \\
\text { progesterone }+ \text { single } \\
\text { injection of oestrogen }\end{array}$ & $\begin{array}{l}24 \\
25 \\
26 \\
27 \\
28 \\
29 \\
30 \\
31 \\
32 \\
33\end{array}$ & $\begin{array}{l}1 \cdot 153 \\
0.381 \\
0.548 \\
0.676 \\
1.135 \\
1.202 \\
1 \cdot 107 \\
1.401 \\
1.869 \\
1.557\end{array}$ & $\begin{array}{l}- \\
+ \\
+ \\
+ \\
+ \\
+ \\
+ \\
+ \\
+\end{array}$ & $\begin{array}{l}+ \\
+ \\
+ \\
+ \\
+ \\
+ \\
+ \\
+ \\
+ \\
+\end{array}$ & $\begin{array}{l}- \\
\overline{-} \\
\overline{+} \\
+ \\
\pm \\
- \\
\overline{+} \\
-\end{array}$ \\
\hline 6. Pseudopregnant & $\begin{array}{l}34 \\
35 \\
36 \\
37 \\
38 \\
39 \\
40\end{array}$ & $\begin{array}{l}6 \cdot 350 \\
5 \cdot 984 \\
5 \cdot 866 \\
7.340 \\
4 \cdot 747 \\
5 \cdot 824 \\
6 \cdot 225\end{array}$ & $\begin{array}{l}+ \\
+ \\
+ \\
+ \\
+ \\
+ \\
+\end{array}$ & $\begin{array}{l}+ \\
+ \\
+ \\
+ \\
+ \\
+ \\
+\end{array}$ & $\begin{array}{l}+ \\
+ \\
+ \\
+ \\
+ \\
+ \\
+\end{array}$ \\
\hline
\end{tabular}

lucent and distended with clear fluid. Histologically, no red cells, polymorphs or tumour cells were visible in the uterine lumen, the endometrium appeared to be intact and the tumour had not invaded the uterine tissues. In spite of the 
complete disappearance of the tumour from within the uterus, it had once again grown well outside in all but one of the animals.

\section{Group 5. Ovariectomized + progesterone + a single injection of oestrogen}

The uterine weights were increased in a number of these animals, and most of them had deciduomata, especially at the points where the uterus had been ligated. As in the Group 3 animals, some of the uteri were visibly distended with blood, and histological examination showed the uterine lumen to be full of red cells, polymorphs and some cells of unknown origin. In three of the animals (Nos. 28, 29 and 32), the tumour appeared to be actively invading the area around the anti-mesometrial deciduoma (see Pl. 1, Fig. 2); however, in all three cases the tumour was also present in an adjacent position outside the uterus, and so it was not possible to tell whether the initial site of invasion had been from within the uterus or from outside it. All but two of the animals in fact showed good tumour growth outside the uterus.

\section{Group 6. Pseudopregnant}

There was a tremendous increase in uterine weight in all the animals of this group; the uterus was grossly distended and lobulated, with a somewhat pearshaped appearance on cross-section. Histologically, the tumour appeared to be invading the anti-mesometrial deciduomata very extensively in all but one of the animals (see Pl. 1, Fig. 3), and many mitoses were present (see Pl. 1, Fig. 4). The tumour had also grown well outside the uterus in all but one of the animals.

\section{DISCUSSION}

Numerous other workers have investigated the fate of tumours transplanted to the uteri of rats, mice, guinea-pigs and hamsters at various stages of the reproductive cycle, and the results have been conflicting. Amongst other factors, this may be due to the size of the inoculum and the amount of damage done to the uterus during inoculation.

Mohs \& Guyer (1937) put small pieces of the Flexner-Jobling carcinoma into the uterine lumen of cycling, spayed, pseudopregnant and lactating rats, and obtained results very similar to our own, with a significant percentage of 'takes' only in the pseudopregnant and lactating groups. They also noted that the tumours only invaded the anti-mesometrial part of the uterus, and in so doing produced a decidual reaction. Homburger, Tregier \& Grossman (1956) used the Walker carcinosarcoma, and found that it grew better in the uteri of mature rather than immature rats, becoming nearly ten times as big as a comparable subcutaneous transplant in 12 days. The endocrine state of the rats was not mentioned. In mice, they found that ovariectomy, oestrogen and oestrogen + progesterone treatment seemed to influence tumour growth outside the uterus, but not inside it. Stein-Werblowsky (1961) found that the Walker tumour grew poorly in the uteri of pseudopregnant rats; when inoculated into the uteri of pregnant rats the tumour grew in $12.5 \%$ of cases $12 \mathrm{hr}$ after mating, but in $61 \%$ of cases at a slightly later stage of gestation. Schlesinger (1962) found no significant difference in the growth rate of a methylcholanthrene-induced 
sarcoma transplanted to the uterus as between non-pregnant and pseudopregnant rats. Working with mice, Hall (1940) found that a sarcoma would develop in the uterus at all stages of the reproductive cycle, whereas Wilson (1963) found that the Harding-Passey melanoma would only implant in the uterus if transferred on Days 3 to 6 of normal pregnancy or pseudopregnancy; outside these time limits, or during di-oestrus, implantation never occurred. As in the rat, implantation was always anti-mesometrial, but it differed in that it was never associated with a decidual reaction.

Our results show that the tumour only invaded the uterus in some of the spayed, progesterone-treated animals given a single injection of oestrogen (Group 5) and the pseudopregnant animals (Group 6). The tumour regularly developed outside the uterus, even though no cells had been intentionally placed there. Decidual tissue was present in Groups 3,5 and 6, but it was only in the latter two groups that the tumour actively invaded it. The response of the uterus to the tumour is obviously under endocrine control, and three different types of response were seen: (1) Complete rejection of the tumour within 7 days, with no residual sign of any cellular reaction (Groups 1, 2 and 4). (2) Rejection of the tumour, leaving the uterus full of blood and polymorphonuclear leucocytes, and a decidual reaction (Group 3). (3) Implantation of the tumour within the deciduoma (Groups 5 and 6).

The rejection mechanisms are unlikely to be due to any immune response, since the tumour was transplanted to rats of the same highly inbred strain as the animals from which it was originally harvested, and it grew well in the abdominal cavity. The endometrial mucosa may serve as a barrier to implantation; it is naturally disrupted in pseudopregnant animals over the deciduoma, and Kirby (1966) has shown that experimental removal of the endothelium in the mouse uterus can give rise to premature implantation of the blastocyst. The hormonal state of the host is known to influence the susceptibility of the uterus to bacterial infection in a number of species, probably due to an effect on the number and phagocytic activity of the leucocytes that reach the uterine lumen (Killingbeck \& Lamming, 1963); but unfortunately, the rat does not seem to be one of the species that is subject to this effect (Lamming \& Heap, 1960).

The behaviour of the tumour in the uterus of the rat is very similar to the behaviour of the blastocyst. The tumour will only implant under the hormonal conditions that would also allow the blastocyst to implant. Furthermore, it implants in the same anti-mesometrial site, and induces the same type of decidual reaction in the endometrium. The blastocyst can only survive in a state of delayed implantation in the spayed, progesterone-treated animal; the delayed implantation state can be terminated by a single injection of $0.1 \mu \mathrm{g}$ oestradiol$17 \beta$ (Cochrane \& Meyer, 1957; Yoshinaga, 1961; Psychoyos, 1961), and implantation will occur about $24 \mathrm{hr}$ later (Yasukawa \& Meyer, 1966). Our results show that in the delayed implantation state, the tumour failed to develop (Group 3), whereas tumour growth occurred in the uteri of three out of seven rats given the 'implanting' injection of $0.2 \mu \mathrm{g}$ oestradiol-17 $\beta$ (Group 5).

Whatever the underlying mechanisms, our results would suggest that the uterus of the rat is highly resistant to the growth of the Walker carcinosarcoma, 
but that it can be made susceptible by the action of steroid hormones. The same also seems to be true of the relationship between the uterus and the blastocyst: the embryo can develop outside the uterus quite independently of the hormonal state or even the sex and species of the host (Kirby, 1965), whereas within the uterus the hormonal requirements are most exacting (Psychoyos, 1966).

\section{ACKNOWLEDGMENTS}

We would like to express our thanks to the Lalor Foundation for financial support (K.Y.), and to Professor Sir Alexander Haddow and Dr M. Whissen for their encouragement and advice. We are also indebted to Miss J. Mavrogordato for her skilled technical assistance.

\section{REFERENCES}

BAEvsKy, V. B. (1963) The effect of embryonic diapause on the nuclei and mitotic activity of mink and rat blastocysts. In: Delayed Implantation, p. 141. Ed. A. C. Enders. University of Chicago Press.

Canivenc, R. \& Laffargue, M. (1956) Survie prolongée d'oeufs fécondés non implantés dans l'utérus de rattes castrées et injectées de progestérone. C.r. hebd. Séanc. Acad. Sci., Paris, 242, 2857.

Cochrane, R. L. \& Meyer, R. K. (1957) Delayed nidation in the rat induced by progesterone. Proc. Soc. exp. Biol. Med. 96, 155.

HALL, B. V. (1940) Influence of the estrus cycle and the decidual reaction on transplanted intrauterine tumors in mice. Yale F. Biol. Med. 13, 333.

Homburger, F., Tregier, A. \& Grossman, M. S. (1956) Tumor growth in hormone-susceptible sites. Comparison of tumor growth and hormonal effects in rodents' uteri and other sites. Cancer Res. 16, 106.

Killingbeck, J. \& Lamming, G. E. (1963) Influence of uterine secretions on phagocytosis. Nature, Lond. 198, 111.

KIRBY, D. R. S. (1965) The role of the uterus in the early stages of mouse development. In: Preimplantation Stages of Pregnancy, p. 325. Eds. G. E. W. Wolstenholme and M. O'Connor. Churchill, London.

KIRBy, D. R. S. (1966) Egg implantation, p. 19. Eds. G. E. W. Wolstenholme and M. O'Connor. Churchill, London.

Lamming, G. E. \& Heap, R. B. (1960) Studies of the uterine environment of different species. II. The influence of ovarian hormones on experimental uterine infections. F. Endocr. 20, xxiv.

Mohs, F. E. \& Guyer, M. F. (1937) Response of the rat endometrium to cancer grafts. Anat. Rec. $69,197$.

Psychoyos, A. (1961) La nidation de la ratte et la dose d'oestrogène nécessaire. C.r. hebd. Séanc. Acad. Sci., Paris, 253, 1616.

Psychoyos, A. (1966) Recent researches on egg implantation. In: Egg Implantation, p. 4. Eds. G. E. W. Wolstenholme and M. O'Connor. Churchill, London.

Rosenoer, V. M., Mrtchley, B. G. V., Roe, F. J. G. \& Connors, T. A. (1966) Walker carcinosarcoma 256 in study of anticancer agents. I. Method for simultaneous assessment of therapeutic value and toxicity. Cancer Res. Suppl. 26, 937.

Schlesinger, M. (1962) Uterus of rodents as a site for manifestation of transplantation immunity against transplantable tumors. F. natn. Cancer Inst. 28, 927.

Short, R. V. \& Hay, M. F. (1966) Delayed implantation in the roe deer Capreolus capreolus. Symp. zool. Soc. Lond. 15, 173.

Stein-Werblowsky, R. (1961) Tumour inhibition during gestation. F. Obstet. Gynaec. Br. Commonw. 68, 498.

Tyndale-Biscoe, C. H. (1963) The role of the corpus luteum in delayed implantation of marsupials. In: Delayed Implantation, p. 15. Ed. A. C. Enders. University of Chicago Press.

Wirson, I. B. (1963) A tumour tissue analogue of the implanting mouse embryo. Proc. zool. Soc. Lond. $141,137$.

Yasukawa, J. J. \& Meyer, R. K. (1966) Effect of progesterone and oestrone on the pre-implantation and implantation stages of embryo development in the rat. F. Reprod. Fert. 11, 245.

YoshinaGA, K. (1961) Effect of local application of ovarian hormones on the delay in implantation in lactating rats. F. Reprod. Fert. 2, 35. 